JURNAL RISET MAHASISWA AKUNTANSI

http://ejournal.unikama.ac.id/index.php/jrma

JRMA, Volume 6, No 2, Oktober 2018

\title{
PENGARUH PROFITABILITAS, STRUKTUR KEPEMILIKAN, DAN SIZE TERHADAP NILAI PERUSAHAAN DENGAN STRUKTUR MODAL SEBAGAI VARIABEL INTERVENING PADA PERUSAHAAN MANUFAKTUR YANG TERDAFTAR DI BURSA EFEK INDONESIA PERIODE 2015
}

\author{
Dessy Prilianti \\ e-mail:_esi.prilianti94@yahoo.com
}

\author{
Abdul Halim \\ Ati Retna Sari \\ (Program Studi Akuntansi, FakultasEkonomika dan Bisnis, UniversitasKanjuruhan, Malang)
}

\begin{abstract}
ABSTRAK
Penelitian ini bertujuan untuk menguji dan menjelaskan pengaruh secara parsial Return on Equity (ROE)), Struktur Keepemilikan (INST), SIZE terhadap nilai perusahaan desngan struktur modal (DER) sebagai variabel intervening pada perusahaan manufaktur yang terdaftar di Bursa Efek Indonesia (BEI). Metode analisis yang digunakan dalam penelitian ini adalah metode kuantitatif, dengan pengujian asumsi klasik, serta analisis statistik yaitu analisis jalur paht. Metode pengambilan sampel yang digunakan adalah purposive sampling. Variabel penelitian ini terdiri dari ROE, INST, SIZE sebagai variabel independen, DER sebagai variabel intervening, dan Nilai perusahaan sebagai variabel dependen dengan total sampel sebanyak 36 perusahaan manufaktur. Hasil Analisis menunjukan bahwa. ROE, INST dan DER secara parsial berpengaruh terhadap nilai perusahaan, dan INST tidak berpengaruh terhadap nilai perusahaan. Untuk penelitian selanjutnya diharapkan dapat menambah variabel-variabel penelitian yang lain.

Kata kunci - Return on Equity (ROE), Struktur Kepemilikan (INST), SIZE, Debt equity Ratio (DER), nilai perusahaan
\end{abstract}

\begin{abstract}
This study aims to test and explain the effect of partially Return on Equity (ROE), Ownership Structure (INST), SIZE on the value of the company with a capital structure (DER) as an intervening variable on manufacturing companies listed on the Indonesia Stock Exchange (IDX). The analytical method used in this study is a quantitative method, by testing classic assumptions, and statistical analysis that is path analysis analysis. The sampling method used was purposive sampling. The variables of this study consisted of ROE, INST, SIZE as an independent variable, $D E R$ as an intervening variable, and company value as the dependent variable with a total sample of 36 manufacturing companies. Analysis results show that. ROE, INST and DER partially affect the value of the company, and INST does not affect the value of the company. For further research, it is expected to add other research variables.
\end{abstract}

Keynotes : Return on Equity (ROE), Ownership Structure (INST), SIZE, Debt equity Ratio (DER), company value 
Dessy Prilianti, Pengaruh Profitabilitas, Struktur Kepemilikan, Dan Size Terhadap Nilai Perusahaan Dengan Struktur Modal Sebagai Variabel Intervening Pada Perusahaan Manufaktur Yang Terdaftar Di Bursa Efek

Indonesia Periode 2015

\section{PENDAHULUAN}

Perusahaan didirikan dengan tujuan untuk memakmurkan pemilik perusahaan atau pemegang saham menurut Suad (2008). Tujuan ini dapat diwujudkan dengan memaksimumkan nilai perusahaan. Mardiyati et al (2012) berpendapat bahwa nilai perusahaan yang go public di pasar modal tercermin dalam harga saham perusahaan, sedangkan nilai perusahaan yang belum go public nilainya terealisasi apabila perusahaan akan dijual, prospek perusahaan, risiko usaha, lingkungan usaha dan lain-lain.

Struktur modal sebagai perimbangan antara penggunaan modal pinjaman dengan modal sendiri Sjahrial (2014). Sedangkan menurut Husnan dan Pudjiastuti (2006) Struktur modal yang mampu memaksimumkan nilai perusahaan atau harga saham adalah struktur modal yang terbaik.

Menurut peneliti terdahulu yaitu Ayu dan Ary (2013) menunjukkan bahwa struktur modal berpengaruh negatif dan signifikan pada nilai perusahaan, profitabilitas berpengaruh positif dan signifikan pada nilai perusahaan, ukuran perusahaan tidak berpengaruh pada nilai perusahaan. Sedangkan menurut peneliti Agnes (2013) hasil penelitian menunjukkan kepemilikan manajerial berpengaruh negatif dan tidak signifikan terhadap nilai perusahaan, struktur modal berpengaruh positif dan signifikan terhadap nilai perusahaan, dan ukuran perusahaan berpengaruh positif dan signifikan terhadap nilai perusahaan. Dan menurut peneliti Novita (2011) mengungkapkan bahwa struktur modal memiliki pengaruh yang positif signifikan terhadap nilai perusahaan, ukuran perusahaan tidak berpengaruh signifikan terhadap nilai perusahaan, profitabilitas berpengaruh positif signifikan terhadap nilai perusahaan. Hasil dari beberapa penelitian tersebut para peneliti hanya menghubungkan variabel independen dengan variabel dependen. Jadi, dalam penelitian ini, peneliti selanjutnya akan memasukkan struktur modal sebagai variabel intervening.

\section{TINJAUAN PUSTAKA}

Perusahaan adalah suatu organisasi yang mengkombinasikan dan mengorganisasi berbagai sumber daya dengan tujuan untuk memproduksi barang atau jasa untuk dijual (Salvatore, 2015). Struktur modal merupakan perbandingan atau imbangan pendanaan jangka panjang perusahaan yang ditunjukkan oleh perbandingan utang jangka panjang terhadap modal sendiri. Profitabilitas adalah kemampuan perusahaan memperoleh laba dalam hubungannya dengan penjualan, total aktiva maupun modal sendiri (Sartono, 2006). Kepemilikan institusional merupakann kondisi dimana institusi memiliki saham dalam suatu perusahaan. Institusi tersebut dapat berupa institusi pemerintah, institusi swasta, domestik maupun asing (Wahyu Widarjo, 2010). Ukuran perusahaan adalah rata-rata total penjualan bersih untuk tahun yang bersangkutan sampai beberapa tahun.

- Pengaruh profitabilitas terhadap struktur modal

Peneliti Veronica dan Hadianto (2008) menemukan bahwa likuiditas, profitabilitas berpengaruh terhadap struktur modal. Tingginya profitabilitas menunjukkan kecukupan laba yang diperoleh perusahaan. Sehingga memungkinkan perusahaan untuk mendanai kegiatan operasionalnya dari dana internal yang dimiliki, tanpa menambah dana dari pemodal luar. Hal ini berarti menurunkan porsi utang dalam susunan struktur modal perusahaan. Dengan demikian hipotesisi pertama adalah: H1 : Profitabilitas berpengaruh secara parsial terhadap struktur modal

- Pengaruh struktur kepemilikan institusional terhadap struktur modal

Peneliti Widjaja dan Kasenda (2008) menunjukkan bahwa kepemilikan institusional berpengaruh negatif signifikan terhadap struktur modal. Penyebab hal ini kemungkinan karena keberadaan pemilik institusional dapat memantau lebih ketat kebijakan pendanaan, sehingga manajemen tidak dapat menggunakan hutang dalam jumlah yang besar hanya untuk kepentingan manajemen sendiri seperti 
Dessy Prilianti, Pengaruh Profitabilitas, Struktur Kepemilikan, Dan Size Terhadap Nilai Perusahaan Dengan Struktur Modal Sebagai Variabel Intervening Pada Perusahaan Manufaktur Yang Terdaftar Di Bursa Efek

Indonesia Periode 2015

melakukan ekspansi besar-besaran untuk membuat kinerjanya seakan-akan terlihat baik. Dengan demikian hipotesisi kedua adalah:

H2 : Struktur Kepemilikan Institusional berpengaruh secara parsial terhadap struktur modal

- Pengaruh size terhadap struktur modal

Perusahaan dengan ukuran yang lebih besar memiliki akses untuk mendapatkan sumber pendanaan dari berbagai sumber sehingga untuk mendapat pinjaman dari kreditur akan lebih mudah karena perusahaan dengan ukuran besar memiliki probabilitas lebih besar untuk memenangkan persaingan dalam industri, sebaliknya perusahaan dengan skala kecil akan lebih menghadapi ketidak pastian, karena perusahaan kecil lebih cepat bereaksi terhadap perubahan yang mendadak. Besar kecilnya ukuran perusahaan akan berpengaruh terhadap struktur modal dengan didasarkan pada kenyataan bahwa semakin besar suatu perusahaan mempunyai tingkat pertumbuhan penjualan yang tinggi sehingga perusahaan tersebut akan lebih berani mengeluarkan saham baru dan kecenderungan untuk menggunakan jumlah pinjaman juga semakin besar pula. Dengan demikian hipotesisi ketiga adalah:

H3 = Size berpengaruh secara langsung terhadap struktur modal

- Pengaruh profitabilitas terhadap nilai perusahaan

Penelitian ini mendukung teori yang dikemukakan Moddigliani Millier bahwa nilai perusahaan ditentukan oleh laba dari aktiva perusahaan. Hasil positif menunjukkan bahwa semakin tinggi laba semakin efisien perputaran aktiva berdampak pada peningkatan nilai perusahaan. Dengan baiknya kinerja perusahaanakan meningkatkan pula nilai perusahaan (Suharli, 2006). Dengan demikian hipotesisi keempat adalah:

H4 = Profitabilitas berpengaruh secara parsial terhadap nilai perusahaan

- Pengaruh Struktur Kepemilikan terhadap nilai perusahaan

Menurut Wening (2009) Semakin besar kepemilikan oleh institusi keuangan maka semakin besar pula kekuatan suara dan dorongan untuk mengoptimalkan nilai perusahaan.. Kepemilikan institusional akan dapat memonitor tim manajemen secara lebih efektif dan nantinya dapat meningkatkan nilai perusahaan. Dengan demikian hipotesisi kelima adalah:

H5 = Kepemilikan institusional berpengaruh secara parsial terhadap nilai perusahaan.

- Pengaruh size terhadap nilai perusahaan

Ukuran perusahaan dianggap mampu mempengaruhi nilai perusahaan, karena semakin besar ukuran atau skala perusahaan maka akan semakin mudah pula perusahaan memperoleh sumber pendanaan baik yang bersifat internal maupun eksternal. Investor mempertimbangkan ukuran perusahaan dalam membeli saham. Ukuran perusahaan dijadikan patokan bahwa perusahaan tersebut mempunyai kinerja bagus. Dengan demikian hipotesisi keenam adalah:

H6 = Ukuran perusahaan berpengaruh secara parsial terhadap nilai perusahaan.

- Pengaruh struktur modal terhadap nilai perusahaan

Penggunaan utang dapat menguntungkan perusahaan karena adanya perlakuan pajak terhadap bunga yang diperhitungkan sebagai biaya dan mengurangi penghasilan kena pajak, sehingga jumlah pajak yang dibayarkan perusahaan berkurang. Struktur modal terkait dengan perusahaan. Dengan mempertimbangkan pajak maka nilai perusahaan akan ditentukan oleh struktur modal. Semakin 
Dessy Prilianti, Pengaruh Profitabilitas, Struktur Kepemilikan, Dan Size Terhadap Nilai Perusahaan Dengan Struktur Modal Sebagai Variabel Intervening Pada Perusahaan Manufaktur Yang Terdaftar Di Bursa Efek

Indonesia Periode 2015

tinggi proporsi utang, maka semakin tinggi nilai perusahaan. Dengan demikian hipotesisi ketujuh adalah:

H7 = Struktur modal berpengaruh secara parsial terhadap nilai perusahaan

- Pengaruh profitabilitas terhadap nilai perusahaan dengan struktur modal sebagai variabel intervening

Profitabilitas merupakan kemampuan perusahaan untuk memperoleh laba atau keuntungan dalam kaitannya dengan penjualan, total aktiva maupun modal sendiri (Sartono, 2008). Profitabilitas yang tinggi memungkinkan perusahaan untuk membiayai investasi maupun operasional perusahaan dari dana sendiri. Sehingga berdampak pada rendahnya utang perusahaan, yang berarti rendahnya pengawasan terhadap manajer oleh pihak luar prusahaan, hal ini merugikan pemegang saham yang berdampak pada penurunan nilai perusahaan. . Dengan demikian hipotesisi kedelapan adalah:

H8 = Profitabilitas berpengaruh terhadap nilai perusahaan dengan struktur modal sebagai variabel intervening.

- Pengaruh struktur kepemilikan institusional terhadap nilai perusahaan dengan struktur modal sebagai variabel intervening

Struktur modal atau keputusan pendanaan akan sangat berpengaruh pada kinerja perusahaan. Keputusan apakah dana yang akan digunakan oleh perusahaan dengan hutang atau dengan penjualan saham akan sangat berpengaruh terhadap kinerja perusahaan khususnya dalam rangka memaksimalkan kemakmuran atau kekayaan para pemegang saham atau pemilik yang akan tercermin melalui harga saham perusahaan. Dengan demikian perusahaan perlu mengusahakan suatu keseimbangan yang optimal dalam menggunakan kedua sumber tersebut sehingga dapat memaksimalkan nilai perusahaan. Dengan demikian hipotesisi kesembilan adalah:

H9 = Struktur kepemilikan institusional berpengaruh terhadap nilai perusahaan dengan struktur modal sebagai variabel intervening.

- Pengaruh size terhadap nilai perusahaan dengan struktur modal sebagai variabel intervening.

Semakin besar size, maka ada kecenderungan lebih banyak investor yang menaruh perhatian pada perusahaan tersebut. Hal ini disebabkan karena perusahaan yang besar cenderung memiliki kondisi yang lebih stabil. Sementara menurut Brigham dan Houston (2011), struktur modal sangat penting bagi perusahaan karena akan berhubungan dan berpengaruh terhadap besarnya risiko yang ditanggung oleh pemegang saham dan besarnya tingkat pengembalian atau tingkat keuntungan yang diharapkan. Sehingga dengan struktur modal yang tepat, tujuan utama perusahaan untuk meningkatkan nilai perusahaan dapat tercapai. Dengan demikian hipotesisi kesepuluh adalah:

H10 = Size berpengaruh terhadap nilai perusahaan dengan struktur modal sebagai variabel intervening . 
Dessy Prilianti, Pengaruh Profitabilitas, Struktur Kepemilikan, Dan Size Terhadap Nilai Perusahaan Dengan Struktur Modal Sebagai Variabel Intervening Pada Perusahaan Manufaktur Yang Terdaftar Di Bursa Efek

Indonesia Periode 2015

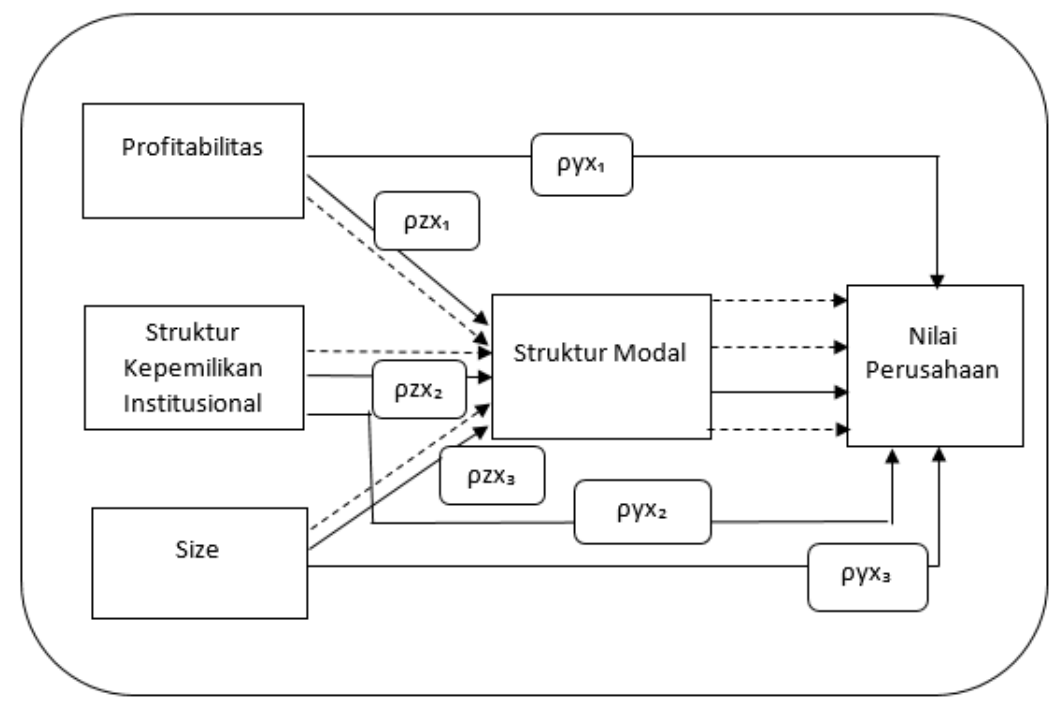

\section{METODE}

Sesuai dengan jenis data yang diperlukan, yaitu data sekunder, teknik pengumpulan datanya adalah dengan cara mengakses melalui www.idx.co.id.

Teknik pengambilan sampel dalam penelitian ini menggunakan purposive sampling atau judgement sampling. Berdasarkan kriteria-kriteria tertentu. Adapun kriteria-kriteria penentuan sampel yang digunakan yaitu, 1) Perusahaan manufaktur yang terdaftar dan aktif di BEI dari tahun 2015, 2) Perusahaan yang mengalami keuntungan, 3) Perusahaan yang menggunakan nilai rupiah. Berdasarkan kriteria tersebut diperoleh sebanyak tiga puluh enam perusahaan manufaktur yang menjadi sampel penelitian ini

\section{Devinisi operasional dan pengukuran variabel}

Variabel dependen dalam penelitian ini adalah nilai perusahaan diukur dengan Tobin'Q. Smithers dan Wright (2008) Tobin'Q memandingkan rasio nilai pasar saham perusahaan dengan nilai buku ekuitas perusahaan, dengan rumus: $\mathrm{Q}=\frac{(E M V+D)}{(E M B+D)}$

$\mathrm{Q}=$ Nilai perusahaan

$\mathrm{EMV}=$ Nilai Pasar dari Ekuitas

$\mathrm{EMB}=$ Nilai Buku dari Ekuitas

$\mathrm{D}=$ Nilai buku dari Hutang

- Variabel Profitabilitas

ROE menunjukkan rentabilitas modal sendiri atau yang sering disebut rentabilitas usaha. Return on equity dapat dihitung dengan formula: $R O E=\frac{\text { Laba Bersih }}{\text { Modal Sendiri }}$

- Variabel struktur kepemilikan Institusional

Struktur kepemilikan merupakan pemisah antara pemilik perusahaan dan manajer perusahaan, pemilik atau pemegang saham adalah pihak yang menyertakan modal kedalam perusahaan. Rumus Struktur Kepemilikan:

$$
\text { INST }=\frac{\text { Jumlah saham }}{\text { Total saham yang beredar }}
$$


Dessy Prilianti, Pengaruh Profitabilitas, Struktur Kepemilikan, Dan Size Terhadap Nilai Perusahaan Dengan Struktur Modal Sebagai Variabel Intervening Pada Perusahaan Manufaktur Yang Terdaftar Di Bursa Efek

Indonesia Periode 2015

- Variabel sizesize

Menunjukkan pengukuran terhadap ukuran perusahaan mengacu pada pendapat Riyanto (2006) dan dimana ukuran perusahaan diproxy dengan nilai logaritma natural dari total penjualan. Secara sistematis dapat diformulasikan sebagai berikut: Size $=$ Ln Total Asset

- Variabel intervening adalah struktur modal.

Struktur modal adalah probabilitas jumlah hutang jangka pendek, hutang jangka panjang, saham preferen, dan saham biasa. Struktur modal dapat diukur dengan rasio perbandingan antara total hutang terhadap modal sendiri yang biasa disebut debt to equity ratio (DER). DER $=\frac{\text { Total Hutang }}{\text { Modal sendiri }}$

\section{Teknik Analisis Data}

Teknik analisis data dalam penelitian ini dengan menggunakan analisis jalur. Metode path analysis merupakan perluasan regresi linier berganda yang digunakan untuk menaksir hubungan kausalitas antara variabel dalam model penelitian yang dibangun berdasarkan landasan teori yang kuat. Persamaan analisi jalur tersebut sebagai berikut:

$$
\begin{gathered}
\mathrm{y}=\rho y x_{1}+\rho y x_{2}+\rho y x_{3}+e_{1} \\
\mathrm{Z}=\rho z x_{1}+\rho z x_{2}+\rho z x_{3}+\rho z y+e_{2}
\end{gathered}
$$

Keterangan:

X1 : Profitabilitas

$\mathrm{X} 2$ : Struktur kepemilikan

X3 : Size

$Y$ : Struktur Modal

Z : Nilai Perushaan

e : variabel lain yang tidak dimasukkan dalam model ini.

Dalam menggunakan alat analisis regresi, perlu dilakukan pengujian asumsi klasik, agar hasil dari analisis regresi ini menunjukkan hubungan yang valid.

- Uji Multikolineritas

Menurut Imam Ghozali (2013) Uji ini bertujuan untuk menguji apakah dalam model regresi ditemukan adanya korelasi antar variabel-variabel bebas. Untuk mengetahui ada tidaknya multikolinieritas adalah dengan melihat nilai VIF (Variance Inflation Factor). Jika nilai tolerance $>0.10$ atau sama dengan nilai VIF < 10, berarti terjadi tidak multikolinierita.

- Uji Heteroskedastisitas

Menurut Imam Ghozali (2013) Uji heteroskedastisitas bertujuan untuk menguji apakah dalam model regresi terjadi ketidaksamaan variance dari residual satu pengamatan ke pengamatan lain, jika variance dari residual satu pengamatan ke pengamatan lain berbeda maka disebut heteroskedastisitas. menggunakan metode scatterplot. Jika grafik plot menunjukkan tidak beraturan, maka dinyatakan tidak terjadi heteroskedastisitas.

- Uji autokorelasi

Bertujuan untuk mengetahui apakah dalam suatu model regresi linier terdapat korelasi antara pengganggu pada periode $t$ dengan kesalahan pada periode $t-1$ (sebelumnya) Ghozali (2013). jika nilai Durbin Watson = 1,55 - 2,46 menunjukkan tidak terjadi autokorelasi

- Uji normalitas

Menurut Imam Ghozali (2013) tujuan dari uji normalitas adalah sebagai berikut: “Uji normalitas bertujuan untuk mengetahui apakah masing-masing variabel berdistribusi normal atau tidak. Suatu data 
Dessy Prilianti, Pengaruh Profitabilitas, Struktur Kepemilikan, Dan Size Terhadap Nilai Perusahaan Dengan Struktur Modal Sebagai Variabel Intervening Pada Perusahaan Manufaktur Yang Terdaftar Di Bursa Efek Indonesia Periode 2015

dinyatakan berdistribusi normal jika nilai Asymp Sig (2-tailed) hasil perhitungan Kolmogorov-Smirnov lebih besar dari 0.05 atau $5 \%$.

- Ujit

Menurut Sugiyono (2012) Tujuan dari uji parsial adalah untuk mengetahui seberapa jauh pengaruh dari variabel independen $(\mathrm{X})$ terhadap variabel dependen $(\mathrm{Y})$ secara parsial. Pengujian hipotesis akan dilakukan dengan menggunakan tingkat signifikansi sebesar 0,05 $(\alpha=5 \%)$. Jika probability value uji-t menunjukkan lebih kecil dari alpha 5\%, maka hipotesis pertama, kedua, ketiga, keempat, kelima, keenam, ketujuh, kedelapan, kesembilan, dan kesepuluh diterima. Sebaliknya, jika nilai probability value uji-t menunjukkan lebih besar dari alpha 5\%, maka hipotesis pertama, kedua, ketiga, keempat, kelima, keenam, ketujuh, kedelapan, kesembilan, dan kesepuluh ditolak.

\section{HASIL DAN PEMBAHASAN}

\section{Uji Asumsi Klasik}

- Uji Multikolinieritas

Hasil uji asumsi klasik multikolinieritas dengan pendekatan VIF (Variance Inflation Factor) dan tolerance untuk semua variabel menunjukkan nilai tolerance lebih besar 0.10 atau nilai VIF lebih kecil dari 10. Hal ini mengindikasikan bahwa tidak terjadi multikolinieritas.

- Uji Autokorelasi

Hasil uji asumsi klasik autokorelasi ini menunjukkan bahwa nilai Durbin Watson 1,851 terletak di antara 1,55 - 2,46 (Firdaus,2010:101). Hal ini mengindikasikan bahwa tidak terjadi autokorelasi.

- Uji Heteroskedastisitas

Hasil uji asumsi klasik heteroskedastisitas menunjukkan bahwa titik titikyang berada pada grafik scatter plot tidak beraturan atau tidak membentuk suatu pola tertentu. Hal ini mengindikasikan bahwa tidak terjadi heteroskedastisitas.

- Uji Normalitas

Hasil uji asumsi klasik normalitas menunjukan bahwa nilai signifikansi Kolmogorof-Smirnov dengan melihat Asymp Sig sebesar 0.967 melebihi 0.05 (5\%). Ini berarti bahwa data variabel pengganggu memiliki distribusi normal.

\section{Hasil Analisis Jalur}

Hasil analisis jalur dapat dibuat persamaan sebagai berikut :

$$
\mathrm{y}=\rho y x_{1}+\rho y x_{2}+\rho y x_{3}+e_{1}
$$

Table 1

\begin{tabular}{|l|l|l|l|}
\hline Variabel & Koefisien Regresi & Nilai Signifikan & Kesimpulan \\
\hline Variabel X1 (ROE) & 0.823 & 0.000 & Berpengaruh \\
\hline Variabel X2 (INZT) & 0.140 & 0.794 & Tidak Berpengaruh \\
\hline
\end{tabular}


Dessy Prilianti, Pengaruh Profitabilitas, Struktur Kepemilikan, Dan Size Terhadap Nilai Perusahaan Dengan Struktur Modal Sebagai Variabel Intervening Pada Perusahaan Manufaktur Yang Terdaftar Di Bursa Efek Indonesia Periode 2015

\begin{tabular}{|l|l|l|l|}
\hline Variabel X3 (SIZE) & 0.107 & 0.000 & Berpengaruh \\
\hline \multicolumn{2}{|l|}{ Nilai R-square $=0.683$} \\
\hline
\end{tabular}

Berdasarkan persamaan jalur yang ditunjukkan pada tabel 1 dapat diartikan bahwa:

1. Nilai konstanta sebesar 3,798 artinya jika variabel ROE, INST dan SIZE nilainya tetap 0, maka nilai DER sebesar 3,798.

2. Nilai koefisien jalur variabel ROE positif 0,823 . Ini menunjukkan bahwa variabel ROE berhubungan positif dengan variabel DER. Artinya jika variabel ROE ditingkatkan satu satuan, maka variabel DER akan naik 0,823 satuan dengan asumsi variabel lainnya tidak berubah.

3. Nilai koefisien jalur variabel INST positif 0,140 . Ini menunjukkan bahwa variabel INST berhubungan positif dengan variabel DER. Artinya jika variabel INST ditingkatkan satu satuan, maka variabel DER akan naik 0,140 satuan dengan asumsi variabel lainnya tidak berubah.

4. Nilai koefisien jalur variabel SIZE positif 0,107. Ini menunjukkan bahwa variabel SIZE berhubungan positif dengan variabel DER. Artinya jika variabel SIZE ditingkatkan satu satuan, maka variabel DER akan naik 0,107 satuan dengan asumsi variabel lainnya tidak berubah.

5. Nilai R-Square 0,683 menunjukkan bahwa perubahan variabel DER 68,3 \% dipengaruhi oleh ROE, INST dan SIZE, sedangkan sisahnya 31.7\% dipengaruhi oleh variabel yang tidak diteliti

Persamaan $2: \mathbf{Z}=\boldsymbol{\rho} \boldsymbol{z} \boldsymbol{x}_{1}+\boldsymbol{\rho z} \boldsymbol{x}_{2}+\boldsymbol{\rho z} \boldsymbol{x}_{3}+\boldsymbol{\rho} \boldsymbol{z} \boldsymbol{y}+\boldsymbol{e}_{2}$

Table 2

\begin{tabular}{|l|l|l|l|}
\hline Variabel & Koefisien Regresi & Nilai Signifikan & Kesimpulan \\
\hline Variabel (ROE) & 0.911 & 0.002 & Berpengaruh \\
\hline Variabel (INZT) & 0.165 & 0.684 & Tidak Berpengaruh \\
\hline Variabel (SIZE) & 0.256 & 0.003 & Berpengaruh \\
\hline Variabel (DER) & 0.511 & 0.004 & Berpengaruh \\
\hline \multicolumn{4}{|l}{ Nilai R-square $=0.683$} \\
\hline
\end{tabular}

Berdasarkan persamaan jalur yang ditunjukkan pada tabel 4.8 diatas dapat diartikan bahwa:

1. Nilai konstanta sebesar 1,698 , artinya jika variabel ROE, INST, SIZE dan DER nilainya tetap 0, maka nilai perusahaan sebesar 1,698.

2. Nilai koefisien jalur variabel ROE positif 0,911. Ini menunjukkan bahwa variabel ROE berhubungan positif dengan variabel nilai perusahaan. Artinya jika variabel ROE ditingkatkan satu satuan, maka variabel nilai perusahaan akan naik 0,911 satuan dengan asumsi variabel lainnya tidak berubah.

3. Nilai koefisien jalur variabel INST positif 0,165. Ini menunjukkan bahwa variabel INST berhubungan positif dengan variabel nilai perusahaan. Artinya jika variabel INST ditingkatkan satu satuan, maka variabel nilai perusahaan akan naik 0,165 satuan dengan asumsi variabel lainnya tidak berubah. 
Dessy Prilianti, Pengaruh Profitabilitas, Struktur Kepemilikan, Dan Size Terhadap Nilai Perusahaan Dengan Struktur Modal Sebagai Variabel Intervening Pada Perusahaan Manufaktur Yang Terdaftar Di Bursa Efek Indonesia Periode 2015

4. Nilai koefisien jalur variabel SIZE positif 0,256 . Ini menunjukkan bahwa variabel SIZE berhubungan positif dengan variabel nilai perusahaan. Artinya jika variabel SIZE ditingkatkan satu satuan, maka variabel nilai perusahaan akan naik 0,256 satuan dengan asumsi variabel lainnya tidak berubah.

5. Nilai koefisien jalur variabel DER positif 0,511. Ini menunjukkan bahwa variabel DER berhubungan positif dengan variabel nilai perusahaan. Artinya jika variabel DER ditingkatkan satu satuan, maka variabel nilai perusahaan akan naik 0,511 satuan dengan asumsi variabel lainnya tidak berubah.

6. Nilai R-Square 0,658 menunjukkan bahwa perubahan variabel return saham $65,8 \%$ dipengaruhi oleh EPS, ROE, DER dan PBV sedangkan sisahnya 34,2\% dipengaruhi oleh variabel yang tidak diteliti.

- Hasil Uji Hipotesis pertama

Berdasarkan tabel 4.13, dapat dilihat nilai probabilitas signifikansi sebesar 0,000 atau lebih rendah dari 0,05 $(0,000<0,05)$. Dengan demikian, hipotesis pertama yang menyatakan bahwa variabel Profitabiitas secara parsial berpengaruh terhadap struktur modal diterima.

- Hasil Uji Hipotesis kedua

Berdasarkan tabel 4.13, dapat dilihat nilai probabilitas signifikansi sebesar 0,794 atau lebih tinggi dari 0,05 $(0,794>0,05)$. Dengan demikian, hipotesis kedua yang menyatakan bahwa variabel institusional secara parsial berpengaruh terhadap struktur modal ditolak.

- Hasil Uji Hipotesis ketiga

Berdasarkan tabel 4.13, dapat dilihat nilai probabilitas signifikansi sebesar 0,000 atau lebih rendah dari $0,05(0,000<0,05)$. Dengan demikian, hipotesis ketiga yang menyatakan bahwa variabel size secara parsial berpengaruh terhadap struktur modal diterima.

- Hasil Uji Hipotesis keempat

Berdasarkan tabel 4.14, dapat dilihat nilai probabilitas signifikansi sebesar 0,002 atau lebih rendah dari $0,05(0,002<0,05)$. Dengan demikian, hipotesis keempat yang menyatakan bahwa variabel profitabilitas secara parsial berpengaruh terhadap nilai perusahaan diterima.

- Hasil Uji Hipotesis kelima

Berdasarkan tabel 4.14, dapat dilihat nilai probabilitas signifikansi sebesar 0,684 atau lebih tinggi dari 0,05 $(0,684>0,05)$. Dengan demikian, hipotesis kelima yang menyatakan bahwa variabel struktur kepemilikan secara parsial berpengaruh terhadap nilai perusahaan ditolak

- Hasil Uji Hipotesis keenam

Berdasarkan tabel 4.14, dapat dilihat nilai probabilitas signifikansi sebesar 0,003 atau lebih rendah dari $0,05(0,003<0,05)$. Dengan demikian, hipotesis keenam yang menyatakan bahwa variabel size secara parsial berpengaruh terhadap nilai perusahaan diterima.

- Hasil Uji Hipotesis ketujuh

Berdasarkan tabel 4.14, dapat dilihat nilai probabilitas signifikansi sebesar 0,004 atau lebih rendah dari 0,05 $(0,004<0,05)$. Dengan demikian, hipotesis ketujuh yang menyatakan bahwa variabel struktur modal secara parsial berpengaruh terhadap nilai perusahaan diterima.

- Hasil Uji Hipotesis kedelapan

Copyright ( J JRMA 2018 ISSN. 2337-5663

Hal | 9 
Dessy Prilianti, Pengaruh Profitabilitas, Struktur Kepemilikan, Dan Size Terhadap Nilai Perusahaan Dengan Struktur Modal Sebagai Variabel Intervening Pada Perusahaan Manufaktur Yang Terdaftar Di Bursa Efek

Indonesia Periode 2015

Nilai sig. jalur $\mathrm{X}_{1}=\Rightarrow \mathrm{Y}\left(\mathrm{P}_{1}\right)$ sebesar 0.000 lebih kecil dari alpa 0.05. Hal ini mengindikasikan bahwa profitabilitas berpengaruh terhadap struktur modal. Semantara itu, nilai sig. jalur $Y=Z\left(\mathrm{P}_{7}\right)$ sebesar 0.004 lebih kecil dari alpa 0.05 . Hal ini mengindikasikan bahwa struktur modal berpengaruh terhadap nilai perusahaan. Maka hipotesis kedelapan yang menyatakan bahwa profitabilitas berpengaruh terhadap nilai perusahaan melalui struktur modal diterima.

- Hasil Uji Hipotesis kesembilan

$\mathrm{X}_{2}=\mathrm{Y}\left(\mathrm{P}_{2}\right)$ sebesar 0.794 lebih besar dari alpa 0.05. Hal ini mengindikasikan bahwa institusional tidak berpengaruh terhadap struktur modal Semantara itu, nilai sig. jalur $Y=\Rightarrow Z\left(\mathrm{P}_{7}\right)$ sebesar 0.004 lebih kecil dari alpa 0.05. Hal ini mengindikasikan bahwa struktur modal berpengaruh terhadap nilai perusahaan. Maka hipotesis kesembilan yang menyatakan bahwa institusional berpengaruh terhadap nilai perusahaan melalui struktur modal ditolak.

- Hasil Uji Hipotesis kesepuluh

Nilai sig. jalur $\mathrm{X}_{3}=>\mathrm{Y}\left(\mathrm{P}_{3}\right)$ sebesar 0.000 lebih kecil dari alpa 0.05. Hal ini mengindikasikan bahwa SIZE berpengaruh terhadap struktur modal. Semantara itu, nilai sig. jalur $Y=\Rightarrow Z\left(P_{7}\right)$ sebesar 0.004 lebih kecil dari alpa 0.05 . Hal ini mengindikasikan bahwa struktur modal berpengaruh terhadap nilai perusahaan. Maka hipotesis kesepuluh yang menyatakan bahwa SIZE berpengaruh terhadap nilai perusahaan melalui struktur modal diterima.

\section{Pembahasan}

Hasil penelitian ini menunjukkan bahwa nilai signifikansi uji-t variabel ROE sebesar 0.000 lebih kecil dari alpa 0,05 dan nilai koefisiennya sebesar 0.802 bertanda positif. Jika variabel ROE dinaikkan satu persen, maka variabel struktur modal juga meningkat sebesar 0.802 persen.

Dalam penelitian ini mengacu pada teori Brigham (2007) yang menyatakan bahwa tingkat keuntungan yang dicapai dari hasil operasional tercemin dalam ROE. Meningkatnya ROE menunjukkan kinerja perusahaan semakin baik, hal ini lebih meningkatkan kepercayaan auditor terhadap perusahaan, sehingga jumlah hutang ada kecenderungan meningkat. Dengan demikina rasio ROE data berpengaruh bila terjadi peningkatan laba ditahan dan tambahan hutang.

Hasil penelitian ini menunjukkan bahwa nilai signifikansi uji-t variabel INST sebesar 0.794 lebih besar dari alpa 0,05 dan nilai koefisiennya sebesar 0.108 bertanda positif. Jika variabel struktur kepemilikan dinaikkan satu persen, maka variabel struktur modal juga meningkat sebesar 0.108 persen. Teori keagenan Jensen \& Meckling dalam Fauz (2007) menyatakan bahwa perusahaan yang memisahkan fungsinya pengelolaan dengan fungsi kepemilikan akan rentan terhadap konflik keagenan. Penyebab konflik antara manajer dan pemegang saham diantaranya menyangkut pembuatan keputusan yang terkait dengan aktivitas pencairan dana dan pembuatan keputusan terkait dengan bagaimana dana yang diperoleh tersebut akan di investasikan. Hal ini disebabkan karena manajer lebih mengutamakan kepentingan pribadi, sehingga akan menurunkan keuntungan dan dividen yang diterima

Hasil penelitian ini menunjukkan bahwa nilai signifikansi uji-t variabel ROE sebesar 0.000 lebih kecil dari alpa 0,05 dan nilai koefisiennya sebesar 0.802 bertanda positif. Jika variabel ROE dinaikkan satu persen, maka variabel struktur modal juga meningkat sebesar 0.802 persen. Semakin besar ukuran suatu perusahaan, maka kecenderungan menggunakan modal asing juga semakin besar. Hal ini disebabkan karena perusahaan besar membutuhkan dana yang besar pula untuk menunjang operasionalnya, dan salah satu alternatif pemenuhannya adalah dengan modal asing apabila modal sendiri tidak mencukupi (Abdul Halim, 2007). Dengan demikian ukuran perusahaan akan memiliki pengaruh terhadap struktur modal.

Hasil penelitian ini menunjukkan bahwa nilai signifikansi uji-t variabel ROE sebesar 0.002 lebih kecil dari alpa 0,05 dan nilai koefisiennya sebesar 0.726 bertanda positif. Jika variabel ROE dinaikkan satu 
Dessy Prilianti, Pengaruh Profitabilitas, Struktur Kepemilikan, Dan Size Terhadap Nilai Perusahaan Dengan Struktur Modal Sebagai Variabel Intervening Pada Perusahaan Manufaktur Yang Terdaftar Di Bursa Efek

Indonesia Periode 2015

persen, maka variabel nilai perusahaan juga meningkat sebesar 0.726 persen. Tingginya minat investor untuk menanamkan modalnya pada perusahaan dengan ROE yang tinggi akan meningkatkan harga saham. ROE mencerminkan tingkat hasil pengembalian investasi bagi pemegang saham (Kusumawati, 2007). Maka, akan terjadi hubungan positif antara profitabilitas dengan harga saham dimana tingginya harga saham akan mempengaruhi nilai perusahaan.

Hasil penelitian ini menunjukkan bahwa nilai signifikansi uji-t variabel ROE sebesar 0.684 lebih besar dari alpa 0,05 dan nilai koefisiennya sebesar 0.131 bertanda positif. Jika variabel struktur institusional dinaikkan satu persen, maka variabel nilai perusahaan juga meningkat sebesar 0.131 persen. Dari hasil ini disimpulkan bahwa jumlah pemegang saham yang besar tidak efektif dalam memonitor perilaku manajer dalam perusahaan. Hal ini mengacu pada teori Siallagan dan Machfoedz, adanya pemisahan kepemilikan dapat menimbulkan konflik dalam pengendalian dan pelaksanaan pengelolaan perusahaan yang menyebabkan para manajer bertindak tidak sesuai dengan keinginan para pemilik yang menyebabkan konflik sehingga struktur kepemilikan belum sepenuhnya berperan sebagai alat monitoring.

Hasil penelitian ini menunjukkan bahwa nilai signifikansi uji-t variabel ROE sebesar 0.003 lebih kecil dari alpa 0,05 dan nilai koefisiennya sebesar 0.326 bertanda positif. Jika variabel struktur institusional dinaikkan satu persen, maka variabel nilai perusahaan juga meningkat sebesar 0.326 persen. Menurut Sujoko (2007) ukuran perusahaan yang besar menunjukkan perusahaan mengalami perkembangan sehingga investor akan merespon positif dan nilai perusahaan akan meningkat. Pangsa pasar relatif menunjukkan daya saing perusahaan lebih tinggi dibanding pesaing utamanya. Investor akan merespon positif sehingga nilai perusahaan akan meningkat.

Hasil penelitian ini menunjukkan bahwa nilai signifikansi uji-t variabel ROE sebesar 0.004 lebih kecil dari alpa 0,05 dan nilai koefisiennya sebesar 0.657 bertanda positif. Jika variabel struktur modal dinaikkan satu persen, maka variabel nilai perusahaan juga meningkat sebesar 0.657 persen. Brigham dan Houston (2007) yang menyatakan bahwa penggunaan hutang juga dapat mempengaruhi harga saham perusahaan. Semakin besar hutang maka akan semakin meningkat nilai perusahaan namun hanya sampai pada batas tertentu saja. Jika melebihi batas tersebut, penggunaan hutang justru akan menurunkan nilai perusahaan. Penggunaan hutang yang semakin besar akan meningkatkan resiko perusahaan.

Hasil penelitian ini menunjukkan bahwa profitabilitas berpengaruh terhadap nilai perusahaan melalui struktur modal, ditunjukkan oleh Nilai sig X1 ke Y sebesar 0.000 lebih kecil dari alpa 0.05, hal ini membuktikan bahwa profitabilitas berpengaruh terhadap struktur modal. Hasil penelitian ini mendukung penelitian Merdianti dkk (2014) yang menemukan bahwa profitabilitas berpengaruh terhadap struktur modal. Semantara itu, nilai sig. jalur Y ke Z sebesar 0.004 lebih kecil dari alpa 0.05 . Hal ini menunjukkan bahwa struktur modal berpengaruh terhadap nilai perusahaan. penelitian ini mendukung penelitian yang dilakukan oleh Karina (2016) yang menyatakan bahwa struktur modal berpengaruh terhadap nilai perusahaan.

Hasil penelitian ini menunjukkan bahwa struktur kepemilikan institusional tidak berpengaruh terhadap nilai perusahaan melalui struktur modal, ditunjukkan oleh Nilai sig. jalur X2 ke Y sebesar 0.794 lebih besar dari alpa 0.05. Hasil ini menunjukkan bahwa struktur kepemilikan institusional tidak berpengaruh terhadap struktur modal. Penelitian ini mendukung peneliti Ananto Z (2015) yang menemukan bahwa struktur kepemilikan institusional tidak berpengaruh terhadap struktur modal. Semantara itu, nilai sig. jalur Y ke Z sebesar 0.004 lebih kecil dari alpa 0.05. menandakan bahwa struktur modal berpengaruh terhadap nilai perusahaan. Penelitian ini mendukung peneliti Karina (2016) yang menyatakan bahwa struktur modal berpengaruh terhadap nilai perusahaan.

perusahaan melalui struktur modal, ditunjukkan oleh Nilai sig. jalur X3 ke Y sebesar 0.000 lebih kecil dari alpa 0.05. Hal ini mengindikasikan bahwa Size berpengaruh terhadap struktur modal. Hasil ini sama dengan peneliti Meidera (2012) yang menemukan bahwa size berpengaruh terhadap struktur modal. 
Dessy Prilianti, Pengaruh Profitabilitas, Struktur Kepemilikan, Dan Size Terhadap Nilai Perusahaan Dengan Struktur Modal Sebagai Variabel Intervening Pada Perusahaan Manufaktur Yang Terdaftar Di Bursa Efek

Indonesia Periode 2015

Semantara itu, nilai sig. jalur Y ke Z sebesar 0.004 lebih kecil dari alpa 0.05. Hal ini mengindikasikan bahwa struktur modal berpenagruh terhadap nilai perusahaan. Penelitian ini mendukung peneliti Karina (2016) yang menyatakan bahwa struktur modal berpengaruh terhadap nilai perusahaan.

\section{Kesimpulan}

Dapat disimpulkan bahwa variabel ROE secara parsial berpengaruh terhadap DER, variabel INST secara parsial tidak berpengaruh terhadap DER, variabel SIZE secara parsial berpengaruh positif terhadap DER, variabel ROE secara parsial berpengaruh terhadap NP, variabel INST secara parsial tidak berpengaruh terhadap NP, variabel SIZE secara parsial berpengaruh positif terhadap NP, variabel DER secara parsial berpengaruh terhadap NP, variabel ROE secara parsial tidak berpengaruh terhadap NP dengan DER sebagai variabel Intervening, variabel INST secara parsial tidak berpengaruh terhadap NP dengan DER sebagai variabel Intervening, variabel SIZE secara parsial tidak berpengaruh terhadap NP dengan DER sebagai variabel Intervening.

\section{Daftar Pustaka}

Agnes. 2013. Pengaruh Kepemilikan Manajemen, Struktur Modal dan Ukuran Perusahaan TerhadapNilai Perusahaan. Jurnal Akuntansi.

Ayu dan Ary. 2013. "Pengaruh Struktur Modal , Profitabilitas, Dan Ukuran Perusahaan Pada Nilai Perusahaan". Jurnal Akuntansi . No. 4.2 : 358-372.

Brigham, E.F. 2007. Fundamentals of Financial Management, 3rd Edition, The Dryden Press, Holt-Saunders Japan.

Brigham, E. F dan Houston, 2007. Dasar-dasar Manajemen Keuangan, Edisi Sepuluh, Alih Bahasa Ali Akbar Yulianto, Penerbit Salemba Empat, Jilid I, Jakarta.

Dermawan Sjahrial. 2014. Manajemen Keuangan (3 th ed). Jakarta: Mitra Wacana Media.

Ghozali, Imam, 2011, Aplikasi analisis multivariate dengan program IBM SPSS 19, Edisi Kelima, Universitas Diponegoro, Semarang.

Gill, Amarjit dan Obradovich, John. 2012. The Impact of Corporate Governance and Financial Leverage on the Value of American Firms. International Research Journal of Finance and Economics. ISSN 1450-2887 Issue 91.

Halim Abdul. (2007). Akuntansi Sektor Publik Akuntansi keuangan daerah, Edisi Revisi, Jakarta, Salemba Empat.

Husnan, S. 2006. Dasar-Dasar Manajemen Keuangan. Edisi Ketiga. UPP AMP YKPN. Yogyakarta

Kartini dan A. Tulus. 2008. Struktur Kepemilikan, Profitabilitas, Pertumbuhan Aktiva dan Ukuran Perusahaan terhadap Struktur Modal pada Perusahaan Manufaktur, Jurnal Keuangan dan Perbankan,12 (1).11-21.

Riyanto, Bambang. 2006. Dasar-dasar Pembelanjaan Perusahaan, Edisi 4 Cetakan Ketujuh, BPFE UGM, Yogyakarta.

Siallagan, Hamonangan dan Machfoedz, M. 2006. Mekanisme Corporate Governance, Kualitas Laba dan Nilai Perusahaan. Disampaikan pada Simposium Nasional Akuntansi (SNA) IX Padang. 
Dessy Prilianti, Pengaruh Profitabilitas, Struktur Kepemilikan, Dan Size Terhadap Nilai Perusahaan Dengan Struktur Modal Sebagai Variabel Intervening Pada Perusahaan Manufaktur Yang Terdaftar Di Bursa Efek Indonesia Periode 2015

Sri Arihta Karina, 2016 Upaya Guru Pendidikan Jasmani Adaptif Dalam Menangani Kesulitan Belajar Siswa Hiperaktif Universitas Pendidikan Indonesia | repository.upi.edu | perpustakaan.upi.edu

Mardiyati, Umi et al. 2012. Pengaruh Kebijakan Dividen, Kebijakan Hutang dan Profitabilitas Terhadap Nilai Perusahaan Manufaktur yang Terdaftar di Bursa Efek Indonesia (BEI) Periode 2005-2010. Jurnal Riset Manajemen Sains Indonesia (JRMSI) Vol. 3, No. 1.

Salvatore, Dominick. 2015. Ekonomi Manajerial dalam Perekonomian Global. Salemba Empat: Jakarta. Schoubben, F., dan C. Van Hulle. 2004."The Determinant of Leverage: Difference beetwen Quoted and Non Quoted Firms", Tijdschriftvoor Economie en Management, XLIX (4): 589-621.

Sartono, Agus. 2006. Manajemen Keuangan: Teori dan Aplikasi, Edisi Keempat, Cetakan Pertama, BPFE, Yogyakarta.

Smithers, Andrew dan Wright, Stephen. 2008. Valuing Wall Street, McGraw Hill.

Suad Husnan dan Eny Pudjiastuti, Dasar-Dasar Manajemen Keuangan, Edisi 5, UPP STIM YKPN, Yogyakarta, 2006.

Sugiyono, 2012. Metode penelitian kuantitatif kualitatif dan R\&D, Alfabeta.

Suharli, Michell. 2006. Studi Empiris Terhadap Faktor yang Mempengaruhi Nilai Perusahaan pada Perusahaan Go Public di Indonesia. Dalam Jurnal Manjemen Akuntansi, 6(1): h: 23-24.

Suryandari, Novita. 2011 . Diklat Analisis Kinerja Perusahaan. Purworejo: STIE Rajawali.

M. Sienly Veronica Wijaya dan Bram Hadianto. 2008. Pengaruh struktur aktiva, ukuran likuiditas, dan profitabilitas terhadap struktur modal emiten sektor ritel di Bursa Efek Indonesia: sebuah pengujian hipotesis pecking order. jurnal Imiah Akuntansi, Volume 7, No. 1 Mei 2008, hal 71-84.

Wahyu Widarjo. Pengaruh Modal Intelektual Dan Pengngkapam Modal Intelektual Pada Nilai Perusahaan. Simposium Nasional Akuntansi XIV, Aceh: 20-23 Juli 2011.

Winahyuningsih, Sumekar, dan Prasetyo.2011.Analisis Faktor-faktor yang Mempengaruhi Struktur Modal Pada Perusahaan Manufaktur yang Go Public di Bursa Efek Indonesia. 